\title{
INFORMATION ECONOMY IN THE CONTEXT OF SUSTAINABLE DEVELOPMENT OF SOCIETY AND ITS EFFECT ON TNC ACTIVITY
}

\author{
Serhii Hushko \\ Prof. DSc, Kryvyi Rih Economic Institute of Kyiv National Economic University named after \\ Vadym Hetman", \\ e-mail: dep.director_edu@kneu.edu.ua, orcid.org/0000-0002-4833-3694, Ukraine \\ Iveta Mietule \\ Prof. PhD, Rezekne Academy of Technologies, \\ e mail: iveta.mietule@ru.lv, orcid.org/0000-0001-7662-9866, Latvia

\section{Kateryna Slyusarenko} \\ Associate Prof. PhD, Kryvyi Rih Economic Institute of Kyiv National Economic University \\ named after Vadym Hetman, \\ e-mail: slusarenko_kv@kneu.dp.ua, orcid.org/0000-0002-2072-2997, Ukraine

\section{Natalia Sheludiakova} \\ Associate Prof. PhD, Kryvyi Rih Economic Institute of Kyiv National Economic University \\ named after Vadym Hetman, \\ e-mail: sheludiakova_na@kneu.dp.ua, orcid.org/0000-0002-6721-8077, Ukraine
}

\begin{abstract}
The article reveals controversial issues regarding definitions of "information economy" concept, defines the types of information economy models. The authors determine the influence of information and communication technologies on achievement of sustainable development goals as well as investigate the development of TNCs in the conditions of the informational economy.
\end{abstract}

Keywords: knowledge economy, information economy, information society, digital economy, information and communication technologies, goals of sustainable development.

DOI: http://dx.doi.org/10.23856/2406

\section{Introduction}

The second industrial revolution brought forth new technologies that transformed the processes of production and distribution of goods and services in the world market. The companies that have taken innovations underwent considerable improvements with optimization the steps in the chain of production and sales. These processes have forced enterprises of different industries and forms of ownership to adapt and apply these new technologies.

Modern economic development is characterized by increasing role and significance of scientific knowledge and innovations for the welfare of society. Moreover, its features include structural shifts from the sphere of real production to the sphere of services, production of information and knowledge, intensive informatization of business processes and society as a whole, globalization and networking of the economy.

The globalization of the economy is a direct consequence of the development of information and communication technologies which enabled the accelerated transactional flows, facilitating the integration of national economic systems into a single production and 
trading area. Consequently, the result of the communication revolution is the formation of a new information economy providing new tools for achieving sustainable development.

Sustainable development is a new philosophical, political and practical model of development for all world countries that have begun the transition from a purely economic model of development to searching an optimal balance between economic, social and environmental components of development. The implementation of this model requires the formation of a public management system for sustainable development which necessarily involves good governance.

In 2015, the United Nations identified 17 Sustainable Development Goals (SDGs) and related areas that will shape international development by 2030. In 2015 there was a global debate on the role of information and communication technologies (ICTs) for sustainable development. The Sustainable Development Summit of the United Nations adopted the 2030 Agenda for Sustainable Development which recognizes the important contribution of ICTs to achieving purposeful, transformational and universal goals of sustainable development.

The incorporation into the information global environment deploys in two contrary directions: on the one hand, under conditions of resource constraints and the growth of various threats to the state-building of underdeveloped countries; on the other hand, advancement of automation, robotization and computerization in the world leading countries. These directions cause radical transformations of socio-economic structures that require the urgent development of organizations of a new economic system ensuring the transfer of human resources to the information industry and the area of system-wide services.

\section{Information economy in the modern world}

Economic development of the second half of the $20^{\text {th }}$ and the beginning of the $21^{\text {st }}$ century is defined by the following trends:

- gradual penetration of information technology into the production process;

- increasing role of scientific knowledge for the welfare of society (both due to the introduction of new technologies and skills improvement of those employed in the economy);

- increasing productivity in the area of production of information technologies and information compared to other fields;

- gradual transition to the predominant production of knowledge and information (due to the increasing number of people employed in this area and their labour efficiency);

- informatization of business processes and society as a whole (information technologies are turning into the growth factor of society welfare);

- globalization that facilitates the acceleration of operations on the world market of goods and capital, the integration of national economic systems into a single production and trading space.

The second half of the $20^{\text {th }}$ century saw the development of several concepts for description of the mentioned tendencies (Kononova, 2015):

- Knowledge Economy, Information Economy (Machlup, 1962);

- Computerized Society (Martin, Norman, 1970);

- Post-Industrial Society (Bell, 1971);

- the Age of Information (Helvey, 1971);

- Information Revolution (Lamberton, 1974);

- Information Economy (Porat, 1978);

- Informational Economy (Castells, 1996); 
- Informatics and Communication Economics (Niiniluto, 1999);

- Technical Economics (Gates, Hemingway, 1999), etc.

Today, there are three consolidated theories derived from the variety of the conceptions: Knowledge Economy, Information Economy and Information Society.

In the literature, the concepts of "Knowledge Economy", "Information Economy" and "Information Society" are often used as equivalents, but there is a significant difference in their meaning.

The concept of "Information Economy" originates from the works of the AustrianAmerican researcher, F. Machlup, who studied the impact of patents on scientific research (Machlup, 1980). The notion of "Knowledge Industry", according to F. Machlup, includes five sectors of information activity within society: education, research and development, media, information technology and information services. His follower M. Porat defined the Information Economy as a cluster of industries producing modern databases and tools ensuring their operation and application (Porat, 1978). M. Porat has expanded the type structure of economic activity by including information activities: four traditional sectors (production of market goods and nonfinancial services; general government; households; nonprofit organizations serving households) were supplemented by two sectors of primary and secondary information.

According to M. Porat, the former embraces industries producing technics for the processing and transmission of information, and provide market information services; the later focuses on planning, programming, marketing of goods and services, as well as the search for and development of new knowledge. The secondary information sector covers all information services of the government system and private business that create information and information technology for the domestic needs of the country (Porat, 1978).

Information economy is the first, initial stage of a new economy of a postindustrial society turning in the course of its development into a knowledge economy. Some consider it as a post-industrial new economy based on the Internet economy.

For instance, the economic encyclopedia notes that the information economy is the feature of the modern economy which provides the spread of information technology in the field of material and non-material production, the transformation of information into one of the important factors of society and individual socio-economic progress.

It is not material goods, but information and spiritual values production and consumption that dominate in information economy, and the level of informatization is its integrative indicator. The material basis of the economy of this kind is the production of electronic information equipment (mass production) and the use of computer systems, machine banks, microprocessors, telecommunication, consumer electronics etc. The information economy assumes the inextricable link between development of information machines and communication systems, which enables the provision of comprehensive information services.

Information economy is an economy in which most of the GDP is provided by production, processing, storing and dissemination of information and knowledge, and more than half of the employees are involved in these activities.

Information economy is characterized by:

- convergence and integration of communication technologies and data processing into information technologies; 
- significant influence of information technologies on economic activity; the influence appears in the fact that most employees are informational workers and most products are information products;

- application of IT networks in all economic institutions, organizations and processes, which leads to increased flexibility, weakening of regulatory control and acceleration of globalization.

The development of the information economy is connected with the formation of the information society. The information society is comprehended as the society in which the creation, distribution, use and manipulation of information becomes the most important economic and cultural activity. According to the OECD, the term "Information Economy" is used to analyze the impact of information technology on the economy (productivity, profitability, employment), while the term "Information Society" serves for the analysis of the social consequences of the use of information and communication technologies (behaviours, relationships within and between communities) (Asprey, Middleton, n.d.). Thus, we can argue that the transition to the economy of information type and the formation of an information society is being accomplished on the basis of sustainable development using ICT.

The study of world experience in the formation of the information economy shows that at the stage of emergence the signs of information economy first appear in business, when particular enterprises, seeking to increase their own profitability by automating routine processes, begin to implement information technology in production and introduce electronic document management. Along with the improvement and increasing accessibility of ICTs, the use of personal computers reaches households and government organizations.

At the second stage, with the development of network technologies, information flows between particular enterprises are formed. Custom production, remote partnership and the possibility of quick decisions making, regardless of the location of contractors, facilitate the establishment of horizontal links and "networking" of business.

At the societal level, ICTs are predominantly used for messaging via email, social networks, and chats. Within public institutions a common database of regulatory documents and statistical reporting is formed.

When ICTs have penetrated all the spheres (business, society, state) and the use of computers has become part of everyday activities, there appear communications between the mentioned elements, first of all, between business and society. Information about business activity becomes public, e-commerce comes into life. Social connections within society expand due to the emergence of new network services - blogs, social networks; the users make their confidential information public.

This stage also involves the introduction of e-government technologies in the sphere of public administration; regulatory and statistical documentation becomes available for enterprises and citizens.

Further development is characterized by increased confidence among the information space agents, which facilitates the expansion of information channels between business and citizens through financial transactions (payments via the Internet become commonplace), citizens get remote work under conditions of freelance. E-commerce becomes an integral part of business.

One of the distinctive features of this stage is strengthening of social ties in society through ICT. Social networks begin to make a profit to their owners due to advertising.

At the next stage, financial flows cover all areas of the information society. In addition to payments between enterprises and citizens, transactions between government structures and 
businesses (taxes, duties, state purchases), government structures and citizens are widely implemented (taxes, pensions, subsidies) (Chugunov, 2008).

After the mechanism for the information exchange between the state, business and citizens has been fully established, and information channels have got credibility, the formation of a new model of public administration is launched. This process, particularly, is reflected in the transition from the concept of E-Government to the concept of E-Governance. E-Government is focused on the openness of government information and the provision of public online services, while the new notion includes concepts of cooperation, participation, consensus and so on (Smorgunov, 2007).

In fact, it is all about e-democracy enabling the citizens to influence the process of adopting and implementing political decisions. According to UN analysts, the implementation of this concept contributes to increased participation and, as a result, public trust in public authorities and the welfare of society as a whole.

Therefore, along with the general features of the information economy formation at the world level, national and regional peculiarities of the evolutionary development of different countries affect the constitution of an informational economy. In this regard there is a need to determine the peculiarities of the implementation of modern models of information-type economy in particular countries (Table 1).

Thus the national and regional features of the functioning of the economic system of the states, form the information economy, affect its formation and development. However, in the world there are still no universal and equally effective methods of ICT development as the basis of the information economy. Therefore, each country approaches this task and develops a model of information-type economy from the standpoint of its own geopolitical, economic, social and cultural interests.

The current development of states under the model of information economy leads to the transformation of processes taking place in the economic, social and political spheres. The paradigm of sustainable development is considered as a new paradigm of social development. Sustainable development focuses primarily on people and improving their quality of life in a favourable socio-economic environment and an eco-friendly, healthy, diverse natural environment. Implementation of the strategy of sustainable development is aimed at overcoming poverty through effective employment, high labour costs, accumulation of human and social capital, development of entrepreneurial activity of the population, strengthening of the middle class, the improvement of social standards and safeguards, as well as providing the necessary social support to vulnerable groups of the population.

Information and communication technologies play a decisive role in promoting the goals of sustainable development. In December 2015, the UN General Assembly discussed the decisions of the World Summit on the Information Society (WSIS + 10) including the statement concerning the ICTs as the main tools for accelerating 17 SDGs in all areas. The 2030 Sustainable Development Program also recognizes that the spread of ICTs and global interconnectivity has great potential for enhancing human progress, bridging the digital divide and developing knowledge societies.

ICTs have clearly demonstrated their value as inter-sectoral mediators that contribute to sustainable development. Thus an intensified use of the Internet can reduce poverty and create jobs by increasing the efficiency and transparency of the government. ICTs can be used to create different disease data banks, and can help governments and decision-making bodies in health planning. ICTs can also contribute to gender equality, women's engagement in policy-making through e-voting and distance learning. 


\section{Information economy models}

\begin{tabular}{|c|c|}
\hline Name & Main features \\
\hline $\begin{array}{l}\text { Anglo-American model (the } \\
\text { USA, Canada, UK, Latin } \\
\text { American countries) }\end{array}$ & $\begin{array}{l}\text { - the dominance of the private sector over the functions of the } \\
\text { state in all areas of society and economic system building; } \\
\text { - intensive development of electronic communications for the } \\
\text { establishment of social, political and cultural ties; } \\
\text { - significant influence of the current legislation on the } \\
\text { development and stimulation of new branches of the economy, } \\
\text { intellectual property rights, social protection of the population. }\end{array}$ \\
\hline $\begin{array}{l}\text { European model (Germany, } \\
\text { France, countries of } \\
\text { Northern Europe, basic } \\
\text { directions are implemented } \\
\text { by the countries of post- } \\
\text { Soviet Community of } \\
\text { Independent States) }\end{array}$ & $\begin{array}{l}\text { - the information economy is formed in the context of the } \\
\text { European integration strategy, with the acceptance of the } \\
\text { priorities of the united Europe; } \\
\text { - variability and political orientation of economic programs } \\
\text { for the information construction economy in different } \\
\text { countries; } \\
\text { - dynamic combination of state interests and aspirations of } \\
\text { private and corporate business, with the consideration of the } \\
\text { fact that the role of each of them can vary in space and time; } \\
\text { - legislation is aimed at protecting existing industries. }\end{array}$ \\
\hline $\begin{array}{l}\text { Japanese model (Southeast } \\
\text { Asian countries) }\end{array}$ & $\begin{array}{l}\text { - orientation to the improvement of the corporate governance } \\
\text { system in all sectors of the economy on the principle of } \\
\text { hierarchical pyramid, based on the triad of conceptual tenets: } \\
\text { gratitude, responsibility, harmony; } \\
\text { - cooperation of the state and the market; } \\
\text { - legislation is weakly adaptive; it inhibits the development of } \\
\text { the information society. }\end{array}$ \\
\hline $\begin{array}{l}\text { Asian model (South Korea, } \\
\text { Taiwan, Singapore, Hong } \\
\text { Kong, Thailand, Malaysia, } \\
\text { Vietnam) }\end{array}$ & $\begin{array}{l}\text { - the state maintains close ties with the private sector, close } \\
\text { cooperation between the state and private capital; } \\
\text { - the state decides on priority investments of the private sector } \\
\text { in the information sphere, stimulates the creation of material, } \\
\text { regional and social infrastructures. }\end{array}$ \\
\hline
\end{tabular}

It should be noted that the role of public authorities is crucial for the advancement of ICTs. Establishing a credible favourable environment for the development and promotion of ICTs can enhance the introduction of SDGs. Public authorities also play an important role in minimizing the risks associated with the use of ICTs, such as cybersecurity, data protection, etc. The state authorities should develop and improve legal mechanisms facilitating the rapid development of technologies. All stakeholders should promote and develop a global online security culture. Secure online space will definitely promote the process of SDGs achievement.

WSIS Forum 2017 that took place in June 2017 in Geneva, showcased many projects that are helping communities achieve their potential. For example, Bridge Africa is a platform that helps companies in Africa market their products, patent their work, and create trademarks. Through e-commerce platforms, the Association Marocaine de l'Indication Géographique de l'Huile d'Argane supports the women producers of Argan tea oil to market 
their products. Project Connect is mapping schools across many developing countries, and measuring the quality of their Internet connectivity. The a2i Programme in Bangladesh has set up 5000 digital centres across the country. The list goes on. The WSIS Prizes, awarded every year, shone a bright light on even more projects (Dumas, n.d).

The realization of projects related to the goals of sustainable development requires significant investments. The development of information technology leads to serious changes in the labour market. By increasing productivity, ICTs facilitate production of more goods and services with less workforce, which leads to technological unemployment. At the same time, innovations create new opportunities for employment in various industries and in emerging markets.

Transnational activities with their inherent features as high intensity of invested capital, knowledge and technology, remain extremely important for development of the world countries. The potential benefits of TNCs are connected to knowledge transfer, technology transfer, managerial skills, new processes, employee training, and access to international production networks and markets.

ICTs play an important role in multinational models and the ability of countries to attract TNCs. However, there is still little evidence of the role of ICTs in determining the ability of countries to benefit from the activities of TNCs. In our opinion, the advantages of transnational activities depend largely on the technological structure of TNCs and the ability of domestic firms to respond to new competition and introduce new technologies. Both of these aspects are influenced by local characteristics of the country, such as the level of human capital, education, the development of local financial markets, the adoption and implementation of ICTs. In turn, the lag in these areas may hamper the efficient use of technology resources on a multinational scale, as well as reduce the ability of domestic industries to absorb foreign know-how and respond to challenges and opportunities provided by foreign actors.

Over the past five years, the influence of information and communication technologies of TNCs in international production has significantly risen. Between 2010 and 2015, the number of technical companies in the UNCTAD's top-100 TNC has more than doubled (Table 2, Table 3).

Table 2

Technical and telecommunication TNCs in the UNCTAD ranking of the top 100

\begin{tabular}{|l|l|l|l|l|l|}
\hline \multicolumn{3}{|c|}{ Tech MNEs } & \multicolumn{3}{c|}{ Telecom MNEs } \\
\hline \multicolumn{1}{|c|}{2000} & \multicolumn{1}{|c|}{2010} & \multicolumn{1}{c|}{2015} & \multicolumn{2}{c|}{2000} & \multicolumn{1}{c|}{2010} \\
\hline Ericsson & HP & Alphabet & Cable \& & Deutsche & Altice \\
HP & IBM & (Google) & Wireless & Telekom & America \\
IBM & Nokia & Apple & SBC & Liberty & Movil \\
LG & Sony & Hon Hai & Telefonica & Orange & Deutsche \\
Motorola & & HP & Verizon & Telefonica & Telekom \\
Sony & & IBM & Vodafone & TeliaSonera & Liberty \\
& & Microsoft & & Vivendi & NTT \\
& & Oracle & & Vodafone & Orange \\
& & Samsung & & & Softbank \\
& & SAP & & & Telefonica \\
& & Sony & & & Vodafone \\
\hline
\end{tabular}


The assets of these TNCs increased by $65 \%$, while their operating income and employees increased by about 30\%, compared with the same trends for the other 100 highest MNEs (World Investment Report 2017). The importance of digital TNCs, including Internet platforms, e-commerce and digital content firms, is also growing rapidly.

Tech MNEs include MNEs working in the field of information technology, computer manufacturing, ICT devices and related components (e.g. Apple, Samsung, Hon Hai), as well as software and service providers (e.g. Microsoft, SAP).

The Telecom MNEs group includes providers of communications and connection infrastructure.

Since the UNCTAD methodology is based on foreign assets, some of the world's leading digital giants, such as Amazon and Facebook, are not included in this ranking. It also does not include major telecom players such as Verizon and AT\&T, whose domestic assets and incomes are very large, but their share of foreign business is relatively small.

Table 2 and 3 reveal that the number of technical and telecommunication TNCs in the top-100 rating did not change significantly. From 2010 to 2015, on the contrary, the number of high-tech companies in the rating more than doubled - from 4 to 10, and their share in total assets and operating income increased by almost 2.5 times (Table 3 ).

Table 3

\section{Evolution of ICT MNEs in UNCTAD's ranking of the top 100 MNEs, 2006 and 2010-2015}

\begin{tabular}{|c|c|c|c|c|c|c|c|c|c|c|c|c|c|c|}
\hline & \multicolumn{2}{|c|}{2006} & \multicolumn{2}{|c|}{2010} & \multicolumn{2}{|c|}{2011} & \multicolumn{2}{|c|}{2012} & \multicolumn{2}{|c|}{2013} & \multicolumn{2}{|c|}{2014} & \multicolumn{2}{|c|}{2015} \\
\hline & 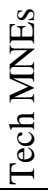 & 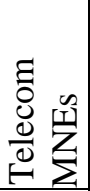 & $\sum_{\frac{n}{2}}^{\tilde{y}}$ & 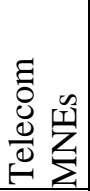 & 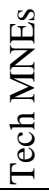 & 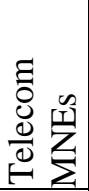 & 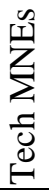 & 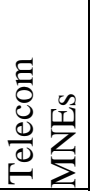 & 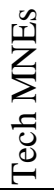 & 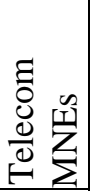 & 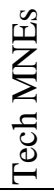 & 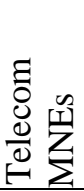 & 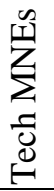 & 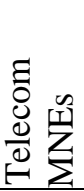 \\
\hline $\begin{array}{l}\text { Number } \\
\text { of firms }\end{array}$ & 6 & 7 & 4 & 7 & 5 & 7 & 7 & 6 & 8 & 6 & 8 & 9 & 10 & 9 \\
\hline $\begin{array}{l}\text { Share in } \\
\text { assets, \% }\end{array}$ & 5 & 6 & 4 & 7 & 4 & 7 & 6 & 6 & 8 & 6 & 8 & 9 & 11 & 9 \\
\hline $\begin{array}{l}\text { Share in } \\
\text { operating } \\
\text { revenues, } \\
\%\end{array}$ & 6 & 4 & 5 & 5 & 5 & 5 & 8 & 4 & 10 & 4 & 10 & 6 & 12 & 7 \\
\hline
\end{tabular}

Source: CUNCTAD, based on UNCTAD's FDI/MNE database, company reports and data from Orbis BvD and Thomson ONE.

The growth is provided by a group of the ranked American Tech MNEs. Some of these companies, such as Alphabet (Google) and Microsoft, are leaders and creators of the digital revolution. Others, such as Oracle, depend on the quality of ICT, the speed of the Internet, with the two later enabling the companies to promote their products on the market and make a profit. In addition, taking into account Telecom MNEs, which are another important component of the digital economy, 19 MNEs of top-100 ranking are ICT companies, which is a significant part of megacorporations. 
Over the past five years, the largest Tech MNEs have taken the lead over traditional MNEs and telecom companies. The assets of these companies grew more than 10 percent a year compared to the assets of the other two groups. The growth of operating income and the number of employees is relatively moderate, but still higher than in other corporations of top100 .

These figures demonstrate that Tech MNEs are currently the most dynamic players among the world's largest multinational corporations.

The rapid growth of Tech MNEs is the result of several interconnected factors:

- rapid technological and market development caused by the digital revolution;

- financial strength and cost-effectiveness through high profitability and liquidity;

- management culture focused on investment and innovation.

As a result, high-tech megacorporations have gained the dominant position in the market both in their main segments and related digital industries. For several years, some of them have become digital hubs working in the full range of information economics.

The average market capitalization of tech megacorporations is almost three times higher than that of other MNEs. At the end of 2015, 10 tech MNEs made up about 26 percent of the total market capitalization of the top-100 MNEs in the UNCTAD ranking, a share over two times larger than their share in number, assets and operating revenues (World Investment Report 2017). Such market capitalization can be largely attributed to highly valuable unrecorded intangibles, such as brand, knowhow and intellectual property (as demonstrated by the wide gap between market value and asset book value). When including this component (calculated according to the market capitalization method), tech MNEs' intangibles are estimated to be roughly equal to their asset book value - significantly more than the average 40 per cent recorded for other MNEs. The second distinctive feature in the asset composition of tech MNEs is the large share of cash and cash equivalents, which stands at 28 per cent of total asset book value, or more than three times higher than the share of cash in other MNEs. Strong liquidity and high spending capacity have fueled the exceptional growth of these companies in recent years.

These major differences in asset profile indicate a structural shift in the sources of corporate value from fixed, tangible assets to intangibles and current assets, and illustrate the profound disruption brought about by digital and tech MNEs. The traditional approach to growth and investment - characterized by high capital expenditure and debt, stretched liquidity, high fixed costs and squeezed margins - is largely absent in the digital world.

UNCTAD has marked the digital economy through the classification of the respective MNEs (Fig. 1)

1. Digital MNEs are characterized by the central role of the internet in their operating and delivery model. They include purely digital players (Internet platforms and providers of digital solutions) that operate entirely in a digital environment and mixed players (ecommerce and digital content) that combine a prominent digital dimension with a physical one.

a. Internet platforms: digitally born businesses, operated and delivered through the Internet, e.g. search engines, social networks and other platforms, such as for sharing.

b. Digital solutions: other Internet-based players and digital enablers, such as electronic and digital payment operators, cloud players and other service providers.

c. E-commerce: online platforms that enable commercial transactions, including Internet retailers and online travel agencies. Delivery may be digital (if the content of the transaction is digital) or physical (if the content is tangible). 
d. Digital content: producers and distributors of goods and services in digital format, including digital media (e.g. video and TV, music, e-books) and games, as well as data and analytics. Digital content can be delivered through the Internet but also through other channels (e.g. cable TV).

2. ICT MNEs provide the enabling infrastructure that makes the Internet accessible to individuals and businesses. They include IT companies selling hardware and software, as well as telecom firms.

a. IT: manufacturers of devices and components (hardware), software developers and providers of IT services

b. Telecom: providers of telecommunication infrastructure and connectivity.

The investment opportunities of global IT companies are growing faster than those of TNCs focused on traditional sectors of the economy. The dividend yield of such companies as Facebook, GOOGL, AMZN and EXPE in 2016 reached 19 percent and the positive trend is expected for the current year. According to data from Table 4, the share of foreign sales of digital MNEs is $40 \%$, while $30 \%$ of their assets are located outside the country. The share of foreign sales of ICT MNEs is $63 \%$, the share of foreign assets reaches $43 \%$.

The data shows that ICT MNEs are developing more intensely. The total sales of ICT MNEs are almost four times the amount of sales of digital MNEs. At the same time, the companies producing devices and components (hardware) and telecommunications account for $85 \%$ of sales.

In respect to sales volume, the third part of the market of IT devices and components belongs to companies such as Apple, Samsung Electronics and Hon Hai Precision Industry. The volume of their sales reaches 500 billion dollars. Samsung Electronics and Hon Hai Precision Industry are presented in one way or another in every country in the world, so more than $90 \%$ of sales are foreign.

The market of telecommunication services is an important part of the global ICT market. Top-100 ICT MNEs include 27 telecommunication companies. At the same time, their share in total capitalization is $44 \%$. By the level of assets, they rank first among top digital and top ICT MNEs. In 2015, the sales of telecommunication companies amounted to 845964 million dollars. Approximately two thirds of this volume is provided by developed countries - North America, Western, Central and Eastern Europe, the leading countries of the Asia-Pacific region.

The sales of digital MNEs is \$ 762875 million, with $46.1 \%$ coming from companies operating in the field of digital media. E-commerce sales have steadily increased over the last five years and come to $23.5 \%$ of the total. The rapid development of e-commerce in the world predetermines its influence on the level of capitalization of companies operating in this area. The main trends in the development of the global e-commerce market include: growth of online purchases; increase in the number of users of the World Wide Web; the drop in prices for computers and software and availability for more consumers; expanding business opportunities without leaving home; extension of international standards for e-business; increase of information and economic interaction of business partners and other contracting parties through the Internet. According to statistics, more than 60 top-100 digital MNEs are US companies, followed by companies from the UK and Northern Ireland and Germany. This concentration is more explicit among Internet platforms: 10 out of 11 large digital TNCs in the rankings are from the USA. 


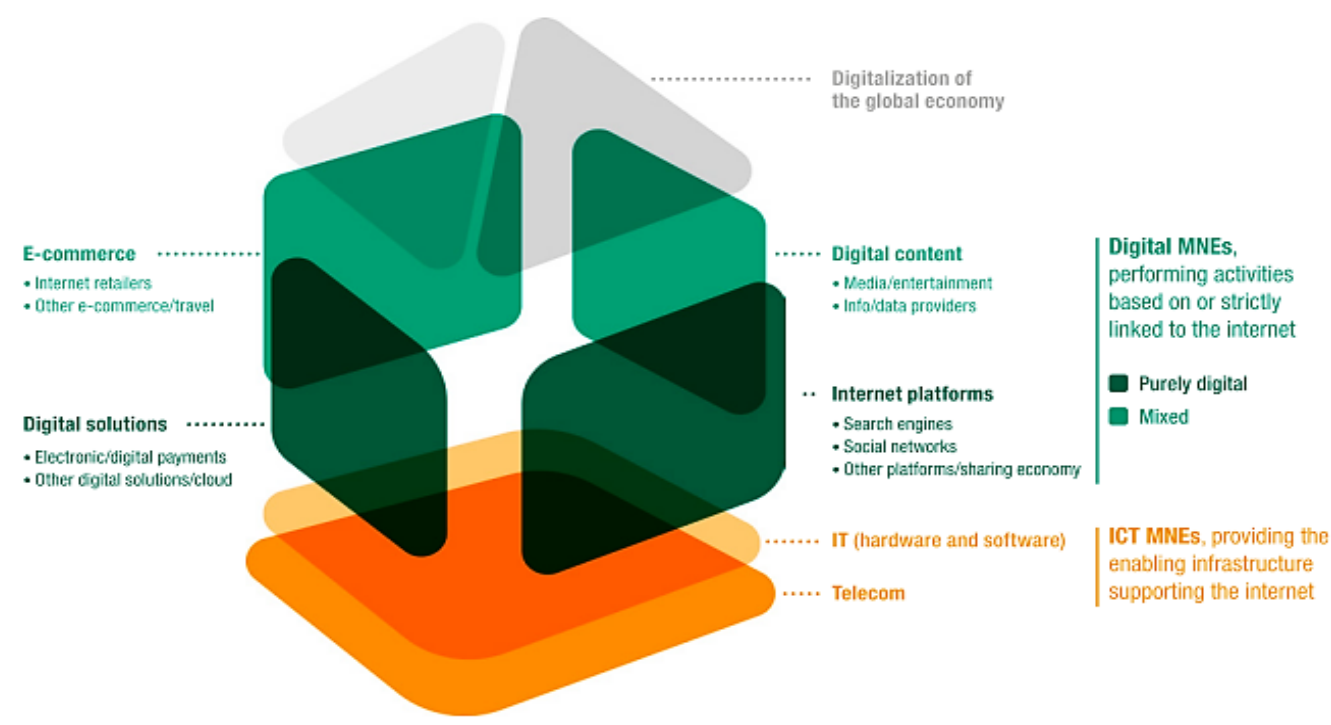

Fig. 1. The architecture of the digital economy (CUNCTAD)

From the table below, one can see that the sectoral affiliation of TNCs has a significant effect on the assets. Accordingly, the dominant position is occupied by corporations of capital-intensive industries, whose foreign property concentrates significant tangible assets.

Table 4

UNCTAD's rankings of top digital and top ICT MNEs (2015)

\begin{tabular}{|c|c|c|c|c|c|c|}
\hline & Company name & & $\begin{array}{c}\text { Total } \\
\text { sales } \\
\text { (\$ million) }\end{array}$ & $\begin{array}{c}\text { Total } \\
\text { assets } \\
(\$ \text { million }) \\
\end{array}$ & $\begin{array}{c}\text { Share of } \\
\text { foreign sales } \\
(\%)\end{array}$ & $\begin{array}{c}\text { Share of } \\
\text { foreign } \\
\text { assets }(\%)\end{array}$ \\
\hline 1 & 2 & 3 & 4 & 5 & 6 & 7 \\
\hline \multicolumn{7}{|c|}{ Top 10 digital MNEs, by sales or operating revenues } \\
\hline \multirow{9}{*}{ 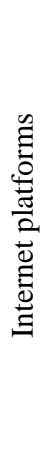 } & Alphabet & Search engines & 74989 & 147461 & 54 & 24 \\
\hline & Facebook & Social networks & 17928 & 49407 & 53 & 21 \\
\hline & eBay & Other platforms & 8592 & 17755 & 58 & 7 \\
\hline & Yahoo & Search engines & 4968 & 45204 & 20 & 6 \\
\hline & IAC/Interactive & Social networks & 3231 & 5189 & 26 & 8 \\
\hline & Groupon & Other platforms & 3120 & 1796 & 34 & 41 \\
\hline & LinkedIn & Social networks & 2991 & 7011 & 38 & 18 \\
\hline & Naver & Search engines & 2773 & 3741 & 33 & NA \\
\hline & Twitter & Social networks & 2218 & 6442 & 35 & 7 \\
\hline
\end{tabular}


Continuation of the table 4

\begin{tabular}{|c|c|c|c|c|c|c|}
\hline \multirow[t]{3}{*}{1} & 2 & 3 & 4 & 5 & 6 & 7 \\
\hline & Red Hat & Other platforms & 2052 & 4155 & 34 & 30 \\
\hline & $\begin{array}{l}\text { Internet platforms to } \\
(11 \text { companies in tot }\end{array}$ & & 123882 & 290071 & 50 & 19 \\
\hline \multirow{11}{*}{ 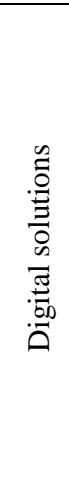 } & $\begin{array}{l}\text { Automatic Data } \\
\text { Processing }\end{array}$ & Other digital solutions & 11668 & 43670 & 15 & 10 \\
\hline & First Data & Electronic payments & 11451 & 34362 & 14 & 11 \\
\hline & PayPal & Electronic payments & 9248 & 28881 & 50 & 7 \\
\hline & Salesforce & Other digital solutions & 6667 & 12763 & 26 & 11 \\
\hline & VMware & Other digital solutions & 6647 & 15746 & 50 & 15 \\
\hline & FIS & Other digital solutions & 6595 & 26269 & 41 & 16 \\
\hline & Worldpay Group & Electronic payments & 5873 & 6122 & 71 & NA \\
\hline & NetApp & Other digital solutions & 5546 & 10037 & 45 & 15 \\
\hline & Insight Enterprises & Other digital solutions & 5373 & 2014 & 32 & 33 \\
\hline & United Internet & Other digital solutions & 4045 & 4222 & 10 & 16 \\
\hline & \begin{tabular}{|l|} 
Digital solutions tota \\
$(26$ companies in tot
\end{tabular} & & 108253 & 252427 & 32 & 17 \\
\hline \multirow{11}{*}{ 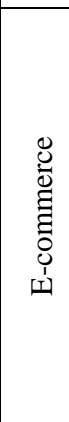 } & Amazon & Internet retailers & 107006 & 65444 & 36 & 32 \\
\hline & Alibaba Group & Internet retailers & 15639 & 56353 & 8 & NA \\
\hline & Priceline Group & Other e-commerce & 9224 & 17421 & 80 & 17 \\
\hline & \begin{tabular}{|l|} 
Expedia \\
\end{tabular} & Other e-commerce & 6672 & 15486 & 44 & 11 \\
\hline & Naspers & Internet retailers & 5930 & 16723 & 54 & NA \\
\hline & Rakuten & Internet retailers & 5922 & 35435 & 20 & 67 \\
\hline & Amadeus IT Group & Other e-commerc & 4260 & 7625 & 96 & 96 \\
\hline & Cnova & Internet retailers & 3804 & 1853 & 50 & 75 \\
\hline & Zalando & Internet retailers & 3221 & 2304 & 47 & $\overline{\mathrm{NA}}$ \\
\hline & Bechtle & Internet retailers & 3076 & 1252 & 31 & 30 \\
\hline & E-commerce total (1 & 8 companies in total) & 178857 & 242613 & 42 & 38 \\
\hline \multirow{11}{*}{ 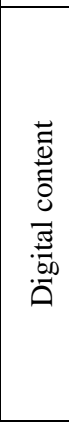 } & Comcast & Digital media & 74510 & 166574 & 8 & NA \\
\hline & Time Warner & Digital media & 28118 & 63848 & 27 & $\overline{\mathrm{NA}}$ \\
\hline & 21st Century Fox & Digital media & 27326 & 48193 & 29 & 10 \\
\hline & Liberty Global & Digital media & 18280 & 67867 & 61 & 63 \\
\hline & \begin{tabular}{|l|} 
Sky \\
\end{tabular} & Digital media & 16138 & 23483 & 30 & 7 \\
\hline & Tencent Holdings & Games & 15846 & 47265 & 6 & 23 \\
\hline & CBS & Digital media & 13886 & 23765 & 14 & 2 \\
\hline & Viacom & Digital media & 12488 & 22508 & 25 & 7 \\
\hline & Thomson Reuters & Info \& data & 12209 & 29095 & 40 & 40 \\
\hline & Liberty Interactive & Digital media & 9989 & 21180 & 26 & 44 \\
\hline \multirow{2}{*}{\multicolumn{3}{|c|}{$\begin{array}{c}\text { Digital content total (45 companies in total) } \\
\text { Total digital }\end{array}$}} & 351883 & 758522 & 36 & 32 \\
\hline & & & 762875 & 1543633 & 40 & 27 \\
\hline \multicolumn{7}{|c|}{ Top 100 ICT MNEs, by sales or operating revenues } \\
\hline \multicolumn{3}{|c|}{ IT devices } & 215639 & 321686 & 65 & 39 \\
\hline \multicolumn{3}{|c|}{ IT devices } & 171126 & 206550 & 90 & 31 \\
\hline \multicolumn{3}{|c|}{ Components } & 135996 & 70038 & 99 & 91 \\
\hline \multicolumn{3}{|c|}{ IT devices } & 81741 & 110495 & 63 & 54 \\
\hline \multicolumn{3}{|c|}{ IT devices } & 71968 & 148037 & 71 & 24 \\
\hline \multicolumn{3}{|c|}{ IT devices } & 55355 & 101459 & 80 & 29 \\
\hline \multicolumn{3}{|c|}{ IT devices } & 50911 & 45122 & 52 & 29 \\
\hline \multicolumn{3}{|c|}{ Components } & 50165 & 48083 & 59 & 36 \\
\hline \multicolumn{3}{|c|}{ IT devices } & 49247 & 121652 & 47 & 20 \\
\hline \multicolumn{3}{|c|}{ IT devices } & 48238 & 29010 & 63 & 58 \\
\hline
\end{tabular}


Continuation of the table 4

\begin{tabular}{|l|c|c|c|c|}
\hline \multicolumn{1}{|c|}{$1-3$} & 4 & 5 & 6 & 7 \\
\hline $\begin{array}{l}\text { IT devices \& components total } \\
\text { (52 companies in total) }\end{array}$ & 1637164 & 1887427 & 75 & 39 \\
\hline IT software \& services & 85320 & 193694 & 52 & 43 \\
\hline IT software \& services & 50123 & 79679 & 61 & 51 \\
\hline IT software \& services & 37047 & 112180 & 53 & 33 \\
\hline IT software \& services & 34798 & 20609 & 99 & 96 \\
\hline IT software \& services & 25048 & 22138 & 21 & 5 \\
\hline IT software \& services & 23554 & 52359 & 98 & 18 \\
\hline IT software \& services & 22637 & 45061 & 87 & 92 \\
\hline IT software \& services & 16379 & 13475 & 93 & 80 \\
\hline IT software \& services & 14338 & 16517 & 31 & 10 \\
\hline IT software \& services & 12972 & 17671 & 79 & 79 \\
\hline IT software \& services total & 409774 & 676177 & 63 & 46 \\
\hline (21 companies in total) & 146801 & 402672 & 4 & 5 \\
\hline Telecom & 102468 & 186770 & 16 & 32 \\
\hline Telecom & 81271 & 183851 & 55 & 66 \\
\hline Telecom & 75368 & 156686 & 64 & 64 \\
\hline Telecom & 59013 & 192587 & 85 & 90 \\
\hline Telecom & 51970 & 75349 & 67 & 46 \\
\hline Telecom & 51407 & 133882 & 72 & 77 \\
\hline Telecom & 43805 & 99540 & 54 & 57 \\
\hline Telecom & 27426 & 61345 & 22 & 10 \\
\hline Telecom & 2892902 & 4582086 & 63 & 43 \\
\hline Telecom & & 77550 & 25 & 12 \\
\hline Telecom total (27 companies in total) & 2018482 & 42 & 46 \\
\hline & & & \\
\hline
\end{tabular}

Source: CUNCTAD, based on UNCTAD's FDI/MNE database, company reports and data from Orbis BvD and Thomson ONE

According to the current world trends, the influence of information technology on the activities of TNCs and the functioning of national economies can be traced in the following:

- simplification of access to foreign markets;

- increasing production of the IT-goods and IT services (electronics, telecommunications, programming, etc.);

- global investment flows are directed to both "mass demand" technology (Internet games, e-commerce) and storage technology for databases, leading to the monopolization of TNCs of intellectual capital and informational digital space;

- TNCs are the main investors in the innovation field, and their financial expenses for innovation activity are constantly increasing;

- a steady increase in the expenses of states and companies for research and development in engineering, ICT, cloud platforms, "large data", nanoscience and microsystem technology, renewable energy sources, energy storage mechanisms, etc.; 
- an increase in the return on available capital (for example, due to more efficient use of resources, reduction of inventories, etc.) which is highly influenced by IT services (programming, system integration, consulting, etc.), and provides an increase in the productivity of existing productions;

- the intensification of innovation competition between TNCs, which leads to the creation of competitive innovative IT products;

- the rapid development of investment ties accompanied by active diffusion of innovative technologies.

\section{Conclusions and suggestions}

The shift to a digital economy in the contemporary world is the priority of policies for all countries. There is a belief that the increase in labour productivity in the United States and in some countries of Europe, Africa and the Middle East is directly caused by the proliferation of information and telecommunication technologies. Economic transformations that have embraced Western Europe in the last decade are a vivid indication of these ties. By investing in the creation of a modern IT infrastructure Western European countries have improved the productivity of their citizens, gained an access to new markets and entered the phase of longterm economic development. For developing countries, the necessity of transition to a digital economy creates both enormous challenges and opportunities. These countries can receive significant economic benefits from ICT development. Digital technologies, services and systems are crucial for social development and the achievement of sustainable development goals. They can enhance the overcoming of the digital divide between countries; ensure growth and creation of new jobs in all sectors of the economy ranging from the smallest traditional enterprises to the newest emerging high-tech industries; ICTs can also contribute to gender equality by involving women in policy-making through e-voting and distance learning.

The IT is one of the leading spheres in the world in terms of income and capitalization. TNCs are key players in the world market of IT products and IT services, whose strengthening has become possible due to the formation of a number of competitive advantages: the strong scientific and technological base, the possibility of financial pressure on the market, as well as the state support when entering the world market.

\section{References}

Asprey, L., \& Middleton, M. (n.d.). Requirements Analysis and Definition Framework. Integrative Document and Content Management. doi:10.4018/9781591400554.ch010. [in English].

Bell, D. (1971). The Coming of Post-Industrial Society. New York: Basic Books. [in English]. Castells, M. (1996). The Information Age: Economy, Society and Culture, Vol. 1: The Rise of the Network Society. Oxford: Blackwell, 150-200. [in English].

Dumas, J. A. (n.d.). WSIS Genderand ICT Policy. Encyclopedia of Genderand Information Technology, 1318-1324. doi:10.4018/978-1-59140-815-4.ch208. [in English].

Gates, B., Hemingway C. (1999). Business @ the Speed of Thought: Succeeding in the Digital Economy. New York: Warner Books. [in English].

Heiets, V. M. (2008). Priorytety natsionalnoho ekonomichnoho rozvytku $v$ konteksti hlobalizatsiinykh vyklykiv. [Monohrafia]. (Heiets V. M., Mazaraki, A. A. red.). Kyiv: Kyivckyi natsionalnyi torhivelno-ekonomichnyi universytet, ch. 1. [in Ukrainian]. 
Helvey, T.C. (1971). The Age of Information: An Interdisplinary Survey of Cybernetics. Englewood Cliffs, NJ: Educational Technology Publications, 6. [in English].

ICTs and Jobs: Complements or Substitutes? (2016). OECD Digital Economy Papers. doi:10.1787/5jlwnklzplhg-en

Information Economy Report 2012. (2012). United Nations Conference on Trade and Development (UNCTAD) Information Economy Report (IER). doi:10.18356/c48133e3-en. [in English].

Information economy report 2013. (2013). United Nations Conference on Trade and Development (UNCTAD) Information Economy Report (IER). doi:10.18356/6a42694a-en. [in English].

Information economy report 2015. (2015). United Nations Conference on Trade and Development (UNCTAD) Information Economy Report (IER). doi:10.18356/d00a8fcc-en. [in English].

Kononova, K. Iu. (2015). Informatsiina ekonomika: modeliuvannia evoliutsiinykh protsesiv. Kharkiv: KhNU imeni V. N. Karazina. [in Ukrainian].

Lamberton, Don M. (1974). The Information Revolution. Philadelphia: Annals of the American Academy of Political and Social Science. [in English].

Machlup, F. (1980). Correspondence: Professor Machlup Replies. Academe, 66(1), 60. doi:10.2307/40249342. [in English].

Martin, J., Norman, A. (1970). The Computerized Society. Harmondsworth: Penguin. [in English].

New Skills for the Digital Economy. (2016). OECD Digital Economy Papers. doi:10.1787/5jlwnkm2fc9x-en. [in English].

Niiniluto, I. (1999). Critical Scientific Realism, Oxford: Clarendon Press. [in English].

Porat, M. (1998). The Information Economy: Definition and Measurement. Rise of the Knowledge Worker, 101-131. doi:10.1016/b978-0-7506-7058-6.50012-0. [in English].

Porat, M. U. (1978). Global Implications of the Information Society. J Communication Journal of Communication, 28(1), 70-80. doi:10.1111/j.1460-2466.1978.tb01565.x. [in English].

Sarokin, D., \& Schulkin, J. (2017). Information and the Market Economy. The MIT Press. doi:10.7551/mitpress/9780262034920.003.0003

Shope-Mafole, L. (n.d.). World Summit on Information Society (WSIS). Telekommunikation und die globale wirtschaftliche Entwicklung, 11-16. doi:10.1007/3-540-26704-2_3. [in English].

Smorgunov, L. V. (2007). Ot jelektronnogo gosudarstva k jelektronnomu pravleniju: Smena paradigmy. Jelektronnoe gosudarstvo $i$ demokratija $v$ nachale XXI veka. Politicheskaja nauka. Moskva: INION, 4, 20-49. [in Russian].

World Investment Report 2017. (2017). United Nations Conference on Trade and Development (UNCTAD.) World Investment Report (WIR). doi:10.18356/e692e49c-en. [in English]. 